\title{
Intramedullary Spinal Neuorocysticercosis
}

\author{
Viroj Wiwanitkit
}

Wiwanitkit House, Bangkhae, Bangkok, Thailand

Dear Editor, the report on "spinal neuorocysticercosis" is very interesting ${ }^{1}$. Kim et al. reported a case and concluded that "Even though the prevalence of intramedullary spinal cysticercosis is extremely rare, and radiologic exams mimic other common tumors like ependymoma or astrocytoma, the disease should be considered as differential diagnosis ${ }^{11}$." In fact, the problem of spinal cysticercosis can be sporadically seen and can be seen at any age group2). As a tissue parasitic infestation, the final diagnosis is usually due to histological examination of surgical specimen. Using MRI, it might be useful for detection of mass lesion, however, it is impossible to differentiate it. Recently Yoo et al. noted that "MR imaging is a sensitive diagnostic tool for detecting cystic lesions in the spine; however, it is difficult to distinguish cysticercosis from non-infectious cysts such as an arachnoid cyst without using gadolinium enhancement ${ }^{3)}$." Del Brutto and Garcia noted that "the visualization of the scolex or the incidental discovery of intracranial lesions provide helpful diagnostic clues ${ }^{4)}$.

\section{REFERENCES}

1. Kim M, Rhim SC, Khang SK. Intramedullary spinal cysticercosis: a case report and review of literature. Korean J Spine 11(2):81-4, 2014

2. Wiwanitkit V. Spinal cysticercosis. Fetal Pediatr Pathol 32(2): 151, 2013

3. Yoo M, Lee CH, Kim KJ, Kim HJ. A case of intradural-extramedullary form of primary spinal cysticercosis misdiagnosed as an arachnoid cyst. J Korean Neurosurg Soc 55(4):226-9, 2014

4. Del Brutto $\mathrm{OH}$, Garcia $\mathrm{HH}$. Intramedullary cysticercosis of the spinal cord: a review of patients evaluated with MRI. J Neurol Sci 331(1-2):114-7, 2013
- Received: August 20, 2014 - Revised: November 31, 2014

- Accepted: December 2, 2014

Corresponding Author: Viroj Wiwanitkit, MD

Hainan Medical University, Wiwanitkit House, Bangkhae, Bangkok, Thailand

Tel: +866624132436, Fax: +866624132436

E-mail:wviroj@yahoo.com

®This is an Open Access article distributed under the terms of the Creative

Commons Attribution Non-Commercial License (http://creativecommons.org/ licenses/by-nc/3.0/) which permits unrestricted non-commercial use, distribution, and reproduction in any medium, provided the original work is properly cited. 